\title{
ANALISIS KLASTER UNTUK PENGELOMPOKAN KABUPATEN/KOTA DI PROPINSI SULAWESI SELATAN BERDASARKAN INDIKATOR KESEJAHTERAAN RAKYAT
}

Wahidah Alwi ${ }^{\mathrm{i}}$, Muh. Hasrul ${ }^{\mathrm{ii}}$

\author{
${ }^{i}$ Prodi Matematika FST, UINAM, Wahidah.alwi@uin-alauddin.ac.id \\ ${ }^{i i}$ Mahasiswa Program Studi Matematika-FST, UINAM
}

ABSTRAK, Tujuan utama dalam pembangunan suatu Negara adalah meningkatkan kesejahteraan rakyat. Salah satu penyebab dari permasalahan kesejahteraan rakyat adalah pembangunan yang dilakukan oleh pemerintah tidak terlaksana secara merata atau dengan kata lain pemerintah dalam melaksanakan pembangunan di suatu daerah tidak tepat sasaran. salah satu solusi yang dapat diterapkan adalah pengidentifikasian karakteristik berdasarkan tingkat kesejahteraan rakyat tiap daerah sehingga pemerintah dapat mengambil atau memutuskan kebijakan dan strategi yang baik/tepat sasaran dalam pembangunan. Dalam penilitian ini akan dibahas mengenai pengelompokan Kabupaten/Kota di Propinsi Sulawesi Selatan berdasarkan indikator kesejahteraan rakyat dengan analisis cluster. Dimana analisis cluster merupakan teknik pengelompokan objek-objek berdasarkan kemiripan karakteristik yang dimiliki. Tujuan dari penelitian ini adalah untuk mengelompokkan Kabupaten/Kota di Propinsi Sulawesi Selatan berdasarkan beberapa indikator kesejahteraan rakyat. Salah satu metode dalam analisis cluster untuk mengelompokkan adalah metode Average Linkage yaitu metode yang ditentukan dari rata-rata jarak seluruh objek pada cluster lainnya. Dari hasil analisis diperoleh bahwa pengelompokan 24 Kabupaten/Kota di Propinsi Sulawesi Selatan dapat dibentuk tiga kelompok (cluster), yaitu Cluster 1 terdiri 21 Kabupaten/Kota dimana cluster ini sangat dipengaruhi oleh variabel Kepemilikan Rumah Sendiri $\left(\mathrm{X}_{11}\right)$. Selain dari variabel PDRB $\left(\mathrm{X}_{1}\right)$ dan Kepemilikan Rumah Sendiri $\left(\mathrm{X}_{11}\right)$ untuk ketujuh variabel lainnya memiliki rata-rata (centroid) yang paling rendah diantara cluster lainnya., Cluster 2 terdiri 2 Kabupaten/Kota dimana pada cluster ini dominan terhadap variabel Rata-Rata Lama Sekolah. Cluster 2, untuk variabel PDRB $\left(\mathrm{X}_{1}\right)$ memiliki rata-rata yang paling rendah. Sedangkan untuk kedelapan variabel lainnya memiliki rata-rata (centroid) yang cukup tinggi (sedang)., dan Cluster 3 terdiri 1 Kabupaten/Kota yaitu Kota Makassar dengan variabel yang mempengaruhi yaitu variabel Kepadatan Penduduk $\left(\mathrm{X}_{2}\right)$. Pada Cluster ini untuk kedelapan variabel lainnya memiliki rata-rata (centroid) yang paling tinggi diantara cluster lainnya. Sedangkan untuk variabel Kepemilikan Rumah Sendiri (X11) merupakan yang paling rendah.

Kata Kunci: Analisis Cluster, Kesejahteraan Rakyat, Average Lingkage

\section{PENDAHULUAN}

Kesejahteraan rakyat selalu menjadi topik yang menarik untuk dibahas.Sebagaimana di setiap negara yang menjadi tujuan utama dalam pembangunan adalah peningkatan kesejahteraan rakyat. Sepertihalnya di Indonesia, kesejahteraan rakyat adalah salah satu tujuan negara yang tertuang dalam Pembukaan UUD 1945 alinea IV.

Kesejahteraan rakyat pada dasarnya merupakan suatu kondisi yang bentuknya dinamis atau dengan kata lain nilai kuantitatifnya tidak akan pernah berhenti karena akan terus berubah seiring dengan perkembangan kebutuhan hidup manusia.

Jumlah penduduk propinsi Sulawesi Selatan Tahun 2015 sebesar 8.520.304 jiwa dengan kepadatan penduduk sekitar186,18 jiwa per kilometer persegi. Jumlah penduduk terus mangalami kenaikan dari tahun ke tahun sebesar $1.8 \%$ atau 10,1 juta. Ketika jumlah penduduk terus bertambah, berarti pemerintah juga harus terus menambah jumlah fasilitas hidup layak bagi masyarakatnya. Selain masalah tentang kependudukan, angka pengangguran di Propins Sulawesi Selatan juga masih tinggi. Sesuai data Tahun 2015, angka pengangguran terbuka mencapai 218.311 jiwa atau sekitar 5,95\%. Dibandingkan tahun sebelumnya dengan tingkat pengangguran terbuka berjumlah 212.857 jiwa atau sekitar 5,08\%. Implikasinya, tingkat pengangguran terbuka akan semakin meningkat, jika tidak ada perubahan strategi dalam penciptaan lapangan kerja. Maka dari itu salah satu solusi guna mengatasi hal tersebut adalah dengan pengidentifikasian karakteristik berdasarkan tingkat kesejahteraan rakyat tiap daerah sehingga pemerintah dapat mengambil 
atau memutuskan kebijakan dan strategi yang baik/tepat sasaran dalam pembangunan

Analisis multivariat merupakan salah satu solusi dalam hal mengelompokkan objek-objek yang mempunyai kesamaan karakteristik. Salah satu dari analisis multivariat yang dapat digunakan yaitu analisis klaster. Analisis klaster bertujuan untuk mengelompokkan objek-objek pengamatan berdasarkan karakteristik yang dimiliki. Ukuran kesamaan yang digunakan adalah ukuran jarak antar objek. Kedua objek yang memiliki jarak paling dekatakan bergabung menjadi satu klaster. Kedekatan jarak yang dimiliki menunjukkan bahwa kedua objek tersebut memiliki tingkat kesamaan karakteristik. Objek penelitian ini adalah tingkat kesejahteraan rakyat dengan 11 indikator yaitu PDRB Tiap Kabupaten/Kota $\left(X_{1}\right)$, Kepadatan Penduduk $\left(X_{2}\right)$, Jumlah Penduduk Miskin $\left(X_{3}\right)$, Daya Beli $\left(X_{4}\right)$, Jumlah Angkatan Kerja $\left(X_{5}\right)$, Angka Harapan Hidup $\left(X_{6}\right)$, Angka Melek Huruf $\left(X_{7}\right)$, Rata-Rata Lama Sekolah $\left(X_{8}\right)$, Angka Harapan Lama Sekolah ( $\left.X_{9} \quad\right)$, Tingkat Pengangguran Terbuka ( $\left.X_{10}\right)$, Kepemilikan Rumah Sendiri $\left(X_{11}\right)$.

\section{TINJAUAN PUSTAKA}

\section{Analisis Multivariat}

Analisis multivariat yaitu analisis yang digunakan terhadap data yang terdiri dari banyak variabel, dimana variabelnya saling berkorelasi satu sama lain, dengan $I=1,2, \ldots n$ dan $\mathrm{j}=1,2$, ...,p. Data multivariat dengan $n$ pengamatan pada $p$ variabel ditampilkan sebagai berikut

$$
\mathbf{X}=\left[\begin{array}{cccccc}
x_{11} & x_{12} & \cdots & x_{1 k} & \cdots & x_{1 p} \\
x_{21} & x_{22} & \cdots & x_{2 k} & \cdots & x_{2 p} \\
\vdots & \vdots & & \vdots & & \vdots \\
x_{j 1} & x_{j 2} & \cdots & x_{j k} & \cdots & x_{j p} \\
\vdots & \vdots & & \vdots & & \vdots \\
x_{n 1} & x_{n 2} & \cdots & x_{n k} & \cdots & x_{n p}
\end{array}\right] \text { Matriks } \quad \mathbf{X}
$$

berisi data yang terdiri dari semua pengamatan terhadap semua variabeldimana $n$ baris dan $p$ kolom.

\section{Analisis Cluster}

Analisi cluster adalah salah satu teknik dari analisis multivariat yang mempunyai tujuan utama yaitu untuk mengelompokkan objek-objek yang berdasarkan kemiripan karakteristik yang dimilikinya. Analisis clusterakan membagi sejumlah data pada satu atau beberapa cluster tertentu. Sebuah cluster yang baik adalah cluster yang memiliki :

- Homogenitas (kesamaan) yang tinggi antara anggota dalam satu cluster(withincluster).

- Heterogenitas (perbedaan) yang tinggi antara cluster yang satu dengan cluster lainnya (between cluster).

\section{Prosedur Analisis Cluster \\ Rumusan Masalah}

Dalam hal ini dilakukan pemilihan variabelvariabel yang akan digunakan untuk pengelompokan (pembentukan cluster). Tahap ini merupakan tahap yang penting karena memilih satu atau dua variabel yang tidak sesuai dengan masalah pengelompokan dan akan menyebabkan penyimpangan pada hasil pengclusteran.

\section{Data Outliers}

Outliers adalah data pengamatan dengan nilainya “ekstrim” yang muncul karena memiliki karakteristik yang unik atau terlihat sangat jauh berbeda dari observasi-observasi lainnya. Deteksi data yang outlier dapat dilakukan dengan melakukan standarisasi data (Z-Score) setelah itu melakukan pengecekan dimana dikatakan sebuah data outlier apabila nilainya tidak terletak dalam selang $(-2,5 ;+2,5)$.

\section{Standarisasi Data}

Perlunya dilakukan proses standarisasi data dengan transformasi pada data asli sebelum dianalisis lebih lanjut apabila variabel yang diteliti memiliki perbedaan ukuran satuan yang besar. Standarisasi dilakukan terhadap variabel yang relevan ke dalam bentuk z-score.

\section{Asumsi-Asumsi}

Terdapat dua asumsi yang harus dipenuhi dalam analisis cluster yaitu sampel mewakili populasi dan tidak terjadi multikolinearitas.Untuk mengetahui apakah sampel yang diambil benar-benar dapat mewakili populasi yang ada dibutuhkan nilai Kaiser-Meyer Olkin (KMO). Dimana nilai KMO kurang dari 0.5 menandakan bahwa sampel yang diambil tidak dapat mewakili populasi yang ada, (Machfudhoh,2013). Sedangkan untuk mendeteksi ada atau tidaknya multikolinearitas dapat dilakukan dengan 
menghitung koefisien korelasi sederhana (korelasi Pearson) antar variabel bebas, jika terdapat nilai yang mencapai atau melebihi 0,8 maka terjadi multikolinearitas. Dalam mengatasi masalah multikolinearitas pada dataadalah dengan Metode Principal Component Analysis (PCA) atau analisis komponen utama

\section{Ukuran Kemiripan Objek}

Dalam menjelasakan atau mengukur kemiripan/kesamaan antar objek digunakan pendekatan ukuran jarak (distance).Semakin besar nilai jarak antara objek berarti semakin besar pula perbedaan karakterstik antara objek.Sedangkan semakin kecil nilai jarak antara objek berarti semakin tinggi pula kemiripan/kesamaan karakteristik antara objek. Terdapat dua pengamatan dalam ruang $p$-dimensi $\mathbf{x}^{\prime}=\left(x_{1}, x_{2}, \ldots, x_{p}\right)$ dan $\quad \mathbf{y}^{\prime}=\left(y_{1}, y_{2}, \ldots, y_{p}\right)$. Jarak dari dua pengamatan tersebut dapat dihitung dalam berbagai cara, seperti jarak Euclid. Jika jarak dua titik xdany ditulis dengan $\mathrm{d}(\mathbf{x}, \mathbf{y})$, rumus perhitungannya dapat dihitung sebagai berikut :

$$
\begin{aligned}
d(\mathbf{x}, \mathbf{y}) & =\sqrt{\left(x_{1}-y_{1}\right)^{2}+\left(x_{2}-y_{2}\right)^{2}+\cdots+\left(x_{p}-y_{p}\right)^{2}} \\
& =\sqrt{(\mathbf{x}-\mathbf{y})^{\prime}(\mathbf{x}-\mathbf{y})}
\end{aligned}
$$

\section{Metode Pengelompokan}

Terdapat dua macam metode dalam proses analisis cluster yaitu metode hirarki dan metode non hirarki. Adapun metode hierarki adalah metode pengelomokan yang terstruktur dan bertahap serta jumlah kelompok atau cluster belum diketahui. Sedangkan pada metode non hirarki, telah ditentukan jumlah kelompok terlebih dahulu.

Pada metode hirarki terdapat dua cara dalam analisis cluster yaitu dengan cara penggabungan(agglomerative) dan pemisahan divisive. Metode hirarki dengan cara penggabungan dilakukan dengan menggabungkan objek secara bertahap, sehingga nantinya hanya diperoleh satu kelompok saja. Sebaliknyacarapemisahan pada metode hirarki dimulai dengan membentuk satu kelompok/cluster besar yang anggotanya seluruh objek pengamatan. Kemudian dipisah menjadi kelompok yang lebih kecil, hingga akhirnya satu kelompok hanya beranggotakan satu objek pengamatan saja.

Dalam penelitian ini menggunakan Average Linkage dalam pengelompokan nya yaitu menentukan rata-rata jarak seluruh objek suatu cluster terhadap seluruh objek pada cluster lainnya. Adapun langkah-langkahnya sebagai berikut :

i.) Menentukan objek bersesuaian yang memiliki jarak terdekat dalam matriks jarak $\mathbf{D}=\left\{d_{i k}\right\}$,

ii.) Menggabungkan objek yang bersesuaian tersebut, katakanlah objek $U$ dan objek $V$, yang kemudian didapatkan cluster(UV).

iii.) Mengitung jarak antara cluster(UV) dengan objek lain katakanlah $W$ yang belum bergabung, dengan rumus

$$
d_{(U V) W}=\frac{\sum_{i} \sum_{k} d_{i k}}{N_{(U V)} N_{W}}
$$

dimana :

$d_{i k}$ :jarak antara obyek $i$ pada cluster $U V$ dan obyek $k$ pada cluster

$W N_{(U V)}:$ Jumlah item pada cluster

$U V N_{W}: J u m l a h$ item pada cluster $U V$ dan $W$

dan menghitung kembali matriks jarak baru dengan cara pada langkah ketiga algoritama cluster hirarki agglomerative secara umum, dan beri nama D2.

iv.) Mengulangi Langkah 2 sampai bergabung menjadi satu cluster.

\section{Interpretasi Cluster}

Tahapan interpretasi cluster adalah untuk mencari karakter setiap kelompok yang khas, salah satunya dapat dilakukan dengan membandingkan mean atau centroid pada setiap kelompok. Adapun cara menghitung mean (centroid)yaitu :

$$
C=\frac{\sum_{j=1}^{n} \sum_{k=1}^{p} x_{j k}}{N}
$$

dimana :

$C$ : Nilai rata-rata (centroid) cluster $x_{j k}$ :Nilai atau data dari objek $j$ pada variabel $k$ dalam cluster yang dicari nilai centroid 
$N$ :Jumlah objek dalam cluster yang dicari nilai centroid

\section{METODOLOGI PENELITIAN}

Data yang digunakan dalam penelitian ini adalah data sekunder yang diperoleh dari BPS Provinsi Sulawesi Selatan yaitu data indikator kesejahteraan rakyat Tahun 2015. Dengan teknik pengumpulan data yaitu (1). Dokumentasi, (2) Observasi, dan (3) wawancara.

Adapun variabel yang digunakan yaitu $\operatorname{PDRB}\left(\mathrm{X}_{1}\right)$ yaitu jumlah nilai barang dan jasa akhir dalam satuan Rupiah yang dihasilkan oleh seluruh unit ekonomi pada suatu daerah, kepadatan penduduk $\left(\mathrm{X}_{2}\right)$ yaitu perbandingan jumlah penduduk dengan luas wilayahnya dalam satuan Jiwa $/ \mathrm{Km}^{2}$, jumlah penduduk miskin $\left(\mathrm{X}_{3}\right)$ yaitu jumlah penduduk yang memiliki rata-rata pengeluaran dibawah garis kemiskinan dalam satuan Jiwa, daya beli $\left(\mathrm{X}_{4}\right)$ yaitu kemampuan masyarakat dalam membelanjakan uangnya dalam bentuk barang maupun jasa dengan satuan Rupiah, jumlah angkatan kerja $\left(\mathrm{X}_{5}\right)$ yaitu jumlah penduduk usia kerja (15 tahun dan lebih) yang bekerja, atau punya pekerjaan namun sementara tidak bekerja dan pengangguran dalam satuan Jiwa, angka harapan hidup $\left(\mathrm{X}_{6}\right)$ yaitu rata-rata tahun hidup dalam satuan Tahun yang masih akan dijalani oleh seseorang yang telah berhasil mencapai umur $x$, pada suatu tahun tertentu, dalam situasi mortalitas yang berlaku di lingkngan masyarakatnya, angka melek huruf $\left(\mathrm{X}_{7}\right)$ yaitu persentase penduduk usia 10 tahun ke atas yang dapat membaca dan menulis dalam huruf latin atau lainnya, dan rata-rata lama sekolah $\left(\mathrm{X}_{8}\right)$ yaitu jumlah tahun belajar penduduk usia 15 tahun ke atas yang telah diselesaikan dalam pendidikan formal (tidak termasuk tahun yang mengulang) dengan satuan Tahun, angka harapan lama sekolah ( $\left.\mathrm{X}_{9}\right)$ yaitu lamanya sekolah yang diharapkan akan dirasakan oleh anak pada umur tertentu di masa mendatang dalam satuan Tahun, tingkat pengangguran terbuka $\left(\mathrm{X}_{10}\right)$ yaitu Persentase pengangguran terhadap jumlah angkatan kerja, dan kepemilikan rumah sendiri $\left(\mathrm{X}_{11}\right)$ yaitu Persentase jumlah rumah tangga dengan status kepemilikan rumah sendiri. Dimana rumah sendiri merupakan jika tempat tinggal tersebut pada waktu pendataan betul-betul sudah milik kepala rumah tangga atau salah satu seorang anggota rumah tangga.

Dalam penelitian ini digunakan analisis cluster hirarki agglomerative dengan metode Averge Linkage, dengan langkah-langkah sebagai berikut: (1) Menentukan objek bersesuaian yang memiliki jarak terdekat dalam matriks jarak $\mathbf{D}=$ $\left\{d_{i k}\right\}$, (2) Menggabungkan objek yang bersesuaian tersebut, katakanlah objek $U$ dan objek $V$, yang kemudian didapatkan cluster (UV), (3) Menghitung jarak antara cluster (UV) dengan objek lain katakanlah $W$ yang belum bergabung dan menghitung kembali matriks jarak baru, (4) Mengulangi langkah 2 sampai bergabung menjadi satu cluster. Hasil dari Average Linkage ini dapat ditampilkan dalam bentuk dendogram atau diagram pohon

Adapun prosedur dari analisis cluster dalam penelitian ini disajikan dalam diagram alur sebagai berikut:

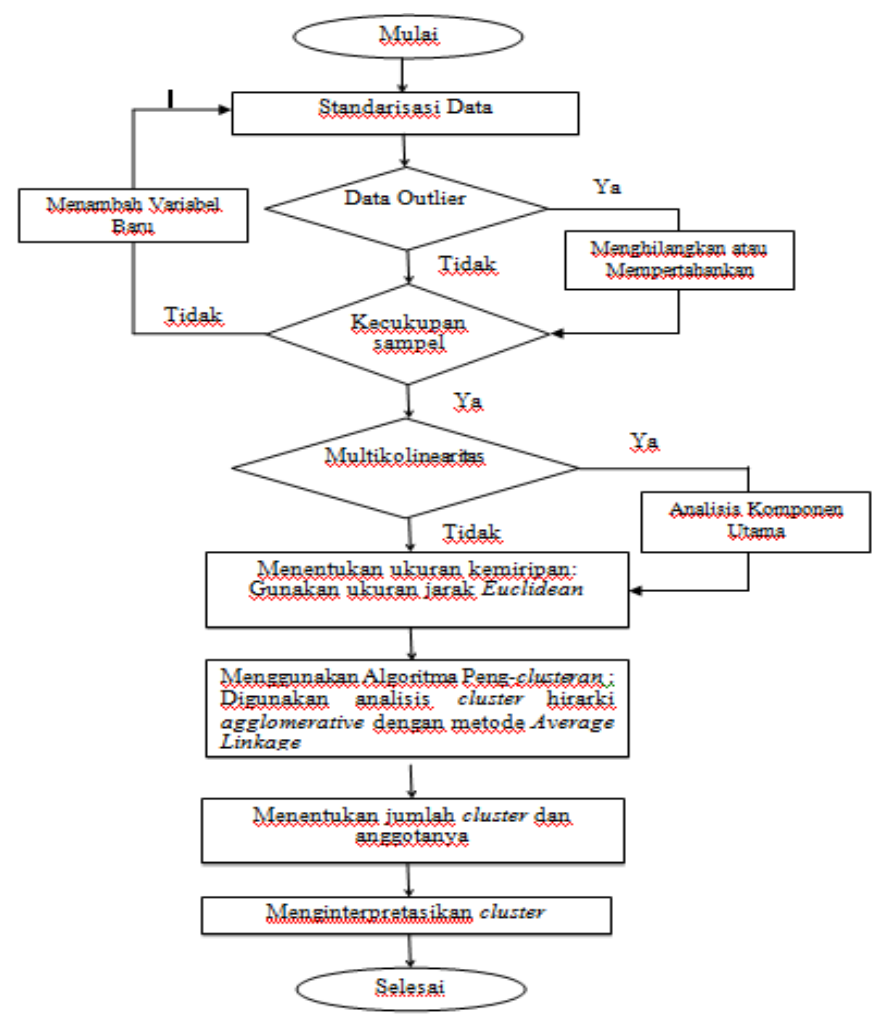

4. HASIL PENELITIAN

\section{Statistika Deskriptif}

Sebelum dilakukan analisis cluster terlebih dahulu dianalisis secara deskriptif.

\section{Tabel 4.1 Statistika Deskriptif Indikator Kesejahteraan Rakyat Tahun 2015}




\begin{tabular}{|l|c|c|c|c|}
\hline \multicolumn{5}{|c|}{ Statistik Deskriptif } \\
\hline Var & Min & Mak & Mean & $\begin{array}{c}\text { Std } \\
\text { Deviasi }\end{array}$ \\
\hline$\left(\mathrm{X}_{1}\right)$ & 2724 & 88740 & 10393 & 17105,97 \\
\hline$\left(\mathrm{X}_{2}\right)$ & 40 & 8246 & 645,4 & 1648,47 \\
\hline $\left.\mathrm{X}_{3}\right)$ & 8,41 & 75,01 & 33,24 & 17,74 \\
\hline$\left(\mathrm{X}_{4}\right)$ & 6,273 & 16,669 & 9,907 & 2,007 \\
\hline$\left(\mathrm{X}_{5}\right)$ & 13542 & 348501 & 121311 & 77104,28 \\
\hline$\left(\mathrm{X}_{6}\right)$ & 65,49 & 72,8 & 68,6 & 2,1 \\
\hline$\left(\mathrm{X}_{7}\right)$ & 83,5 & 98,22 & 91,82 & 3,33 \\
\hline$\left(\mathrm{X}_{8}\right)$ & 5,64 & 10,77 & 7,54 & 1,23 \\
\hline$\left(\mathrm{X}_{9}\right)$ & 11,61 & 15,02 & 12,82 & 0,91 \\
\hline$\left(\mathrm{X}_{10}\right)$ & 0,9 & 12,07 & 5,23 & 2,96 \\
\hline$\left(\mathrm{X}_{11}\right)$ & 68,22 & 98,84 & 88,22 & 8,59 \\
\hline
\end{tabular}

Berdasarkan Tabel 4.1 diperoleh nilai minimum, maksimum, mean dan standar variasi dari sebelas variabel.Nilai tersebut menggambarkan perbedaan karekteristik dari setiap variabel.

Sebelum di lakukan uji asumsi terlebih dahulu dilakukan standarisasi data yang dilakukan apabila terdapat perbedaan satuan yang signifikan diantara variabel-variabel yang diteliti. Karena dalam penelitian ini, data yang digunakan satuan variabelnya berbeda maka dilakukan stndarisasi data terlebih dahulu.

Selanjutnya, berdasarkan data penelitian yang telah distandarisasi, jika ada data yang nilainya tidak berada diantara $\pm 2,5$ berarti data tersebut outlier. Hasil pengamatan terhadap data yang outlier ditampilkan dalam Tabel 4.15 sebagai berikut :

Tabel 4.2. Deteksi Outlier

\begin{tabular}{|c|c|c|}
\hline Kab/Kota & Variabel & Nilai \\
\hline Bone & $Z X_{5}$ & 2,94652 \\
\hline \multirow{3}{*}{ Makassar } & $Z X_{1}$ & 4,5801 \\
\cline { 2 - 3 } & $Z X_{2}$ & 4,61067 \\
\cline { 2 - 3 } & $Z X_{4}$ & 2,87021 \\
\cline { 2 - 3 } & $Z X_{8}$ & 2,61633 \\
\hline
\end{tabular}

Berdasarkan Tabel 4.2 diperoleh data outlie, langkah berikutnya adalah tetap mempertahankan data outlier tersebut karena merupakan representasi dari populasi yang diteliti. Data yang outlier ini memberikan gambaran bahwa Kabupaten Bone dan Kota Makassar pada variabel tertentu sangat berbeda karakteristiknya dibanding dengan kabupaten/kota lainnya yaitu: jumlah angkatan kerja $\left(\mathrm{ZX}_{5}\right)$ di Kab. Bone sangat berbeda dengan kabupaten yang lain, begitupula PDRB $\left(\mathrm{ZX}_{1}\right)$ Kota Makassar sangat berbeda dengan PDRB di kabupaten yang lainnya, kepadatan penduduk $\left(Z_{2}\right)$, daya beli $\left(Z_{4}\right)$ dan rata-rata lama sekolah $\left(\mathrm{ZX}_{8}\right)$ sangat berbeda dengan kabupaten yang lainnya.

\section{Uji Asumsi}

\section{Uji Kecukupan Sampel}

Uji kecukupan sampel bertujuan untuk menguji apakah sampel yang digunakan cukup untuk dianalisis lebih lanjut, dapat dilihat dari nilai Kaiser Meyer Olkin (KMO).

Hipotesis :

$\mathrm{H}_{0}$ : Sampel belum cukup untuk dianalisis lebih lanjut

$\mathrm{H}_{1}$ : Sampel sudah cukup untuk dianalisis lebih lanjut

Statistik uji: $K M O=\frac{\sum_{i=1}^{p} \sum_{j=1}^{p} r_{i j}{ }^{2}}{\sum_{i=1}^{p} \sum_{j=1}^{p} r_{i j}{ }^{2}+\sum_{i=1}^{p} \sum_{j=1}^{p} \rho_{i j}{ }^{2}}$

Pengambilan keputusan : nilai KMO> 0,5 maka tolak $\mathrm{H}_{0}$.

Tabel 4.3 Uji KMO

\begin{tabular}{|l|l|l|}
\hline \multicolumn{2}{|c|}{ Uji } & \multicolumn{1}{c|}{ Nilai } \\
\hline KMO & 0,694 \\
\hline \multirow{3}{*}{$\begin{array}{c}\text { Bartlett's } \\
\text { Test Of } \\
\text { Sphericity }\end{array}$} & $\begin{array}{l}\text { Square Chi- } \\
237,71\end{array}$ & \\
\cline { 2 - 3 } & Sig & 55 \\
\hline
\end{tabular}

Berdasarkan Tabel 4.3 menunjukkan bahwa nilai KMO sebesar 0,694. Karena 0,694 > 0,5 berarti tolak $\mathrm{H}_{\mathrm{o}}$ sehingga dapat disimpulkan sampel digunakan sudah cukup untuk dianalisis lebih lanjut.

\section{Uji Multikolinearitas}

Dalam mengetahui ada tidaknya multikolinearitas dapat dilihat dari nilai koefisien korelasi sederhana (korelasi Pearson). Jika terdapat nilai yang mencapai atau melebihi $\pm 0,8$ maka terjadi multikolinearitas. Setelah dilakukan perhitungan menggunakan program $R$ diperoleh hasil bahwa variabel $X_{1}$ dengan $X_{2}, X_{7}$ dengan $X_{8}$, $X_{8}$ dengan $X_{9}, X_{8}$ dengan $X_{11}$ serta $X_{9}$ dengan $X_{11}$ mengalami multikolinearitas karena nilai korelasi lebih dari $\pm 0,80$. Maka dari itu dilakukan analisis komponen utama atau principal component analysis untuk mengatasi masalah tersebut.

\section{IV.3 Principal Component Analysis}


Dalam analisis komponen utama ada beberapa asumsi yang harus terpenuhi yaitu :

\section{a. Uji Kecukupan Sampel}

Uji ini telah dilakukan sebelumnya dan diperoleh nilai KMO sebesar 0,694 (Tabel 4.2) dan telah memenuhi asumsi.

\section{b. Uji Bartlett}

Uji ini bertujuan untuk mengetahui ada tidaknya korelasi antar variabel

Hipotesis :

$\mathrm{H}_{0}: \mathbf{R}=\mathbf{I}$ (Tidak ada korelasi)

$\mathrm{H}_{1}: \mathbf{R} \neq \mathbf{I}$ (Terdapat korelasi)

Statistik uji :

$\chi^{2}$ hitung $=-\left\{n-1-\frac{2 p+5}{6}\right\} \ln |\mathbf{R}|$

Pengambilan keputusan : Tolak $\mathrm{H}_{0}$ jika $\chi^{2}$ hitung $>\chi_{\alpha ; \frac{1}{2} p(p-1)}^{2}$ atau sig. $<\alpha=0,05$

Adapun hasil pengujian Bartlett dapat di lihat pada Tabel 4.3 sebagai berikut :

Tabel 4.4 Uji Bartlett

\begin{tabular}{|c|l|c|}
\hline \multicolumn{2}{|c|}{ Uji } & \multicolumn{1}{c|}{ Nilai } \\
\hline \multirow{3}{*}{$\begin{array}{c}\text { Bartlett's } \\
\text { Test }\end{array}$} & $\begin{array}{l}\text { Approx. } \\
\text { Chi- } \\
\text { Square }\end{array}$ & 237,71 \\
\cline { 2 - 3 } & df & 55 \\
\cline { 2 - 3 } & sig & $2.2 \mathrm{e}-16$ \\
\hline
\end{tabular}

Berdasarkan Tabel 4.4 menunjukkan bahwa nilai $p$-value sebesar 2.2e-16. Karena $p$ value $<0,05$ berarti tolak $\mathrm{H}_{0}$ sehingga dapat disimpulkan terdapat korelasi antar variabel.

\section{c. Nilai MSA}

Tabel 4.5 Nilai MSA

\begin{tabular}{|l|r|}
\hline Var & MSA \\
\hline X1 & 0,609 \\
\hline X2 & 0,645 \\
\hline X3 & 0,341 \\
\hline X4 & 0,768 \\
\hline X5 & 0,424 \\
\hline X6 & 0,568 \\
\hline X7 & 0,682 \\
\hline X8 & 0,783 \\
\hline X9 & 0,802 \\
\hline X10 & 0,813 \\
\hline X11 & 0,78 \\
\hline
\end{tabular}

Nilai MSA digunakan untuk mengetahui variabel-variabel mana saja yang layak dilakukan $P C A$. Nilai MSA yang kurang dari 0,5 menunjukkan bahwa variabel tersebut tidak layak untuk dianalisis PCA. Adapun hasil perhitungan nilai MSA dari kesebelas variabel yang ditampilkan dalam Tabel 4.5.

Berdasarkan Tabel 4.5 dari sebelas variabel yang ada, variabel $X_{3}$ dan $X_{5}$ masing-masing memliki nilai $M S A$ kurang dari 0,5 sehingga hanya kesembilan variabel yang layak untuk dilakukan PCA.

Selanjutnya melakukan analisis komponen utama dengan langkah-langkah sebagai berikut :

1. Membuat matrks $\mathbf{Z}$ yang berisi data variabel yang distandarisasi

2. Membuat matriks korelasi $\mathbf{R}$ yaitu dengan rumus :

$$
\mathbf{R}=\frac{1}{n-1} \mathbf{Z}^{\prime} \mathbf{Z}
$$

3. Mencari nilai eigen $\lambda_{1}, \lambda_{2}, \ldots, \lambda_{\mathrm{p}}$ yang memenuhi persamaan

$$
|\mathbf{R}-\lambda \mathbf{I}|=0
$$

4. Mencari eigen vector $\left(\hat{e}_{i}\right)$ yang bersesuaian dengan nilai eigen dan memenuhi persamaan

$$
(\mathbf{R}-\lambda I) \cdot \hat{\mathbf{e}}_{i}=0
$$

5. Menentukan banyaknya komponen yang dipilih berdasarkan nilai eigen yang menjelaskan besarnya kontrobusi keragaman atau varian masing-masing komponen utama. Nilai eigen selalu diurutkan dari yang terbesar ke terkecil.

6. Bentuk persamaan komponen $(P C)$ seperti berikut :

$$
P C_{i}=\hat{\mathbf{e}}_{i} \mathbf{z}=\hat{e}_{i 1} z_{1}+\hat{e}_{i 1} z_{1}+\cdots \cdots+\hat{e}_{i p} z_{p}
$$

Setelah dilakukan langkah-langkah seperti di atas diperoleh bahwa Komponen 1 dan Komponen 2 secara bersama-sama telah dapat menjelaskan keragaman atau variansi dari kesembilan variabel sebesar 79,89 \%.Selanjutnya menentukan eigen vector atau koefisien dari principal component yang akan digunakan untuk membentuk persamaan $P C$ sebagai berikut :

$$
\begin{aligned}
P C_{1}= & 0,287 z_{1}+0,313 z_{2}+0,313 z_{4}+0,246 z_{6}+ \\
& 0,345 z_{7}+0,394 z_{8}+0,372 z_{9}+0,329 z_{10}- \\
& 0,376 z_{11} \\
P C_{2}= & -0,510 z_{1}-0,450 z_{2}-0,341 z_{4}+0,467 z_{6}+ \\
& 0,224 z_{7}+0,171 z_{8}+0,217 z_{9}-0,121 z_{10}- \\
& 0,249 z_{11}
\end{aligned}
$$

Selanjutnya adalah menghitung PCscore dari kedua persaman $P C$. Nilai $P C$ score inilah yang digunakan untuk analisis lebih lanjut. 


\section{Ukuran Kemiripin Objek}

Menghitung kemiripan antar objek dengan menggunakan jarak Euclidean. Dihitung jarak antara Kab. Kepulauan Selayar dan Kab. Bulukumba (obyek 1 dan 2 ).

$$
\begin{aligned}
d(1,2) & =\sqrt{\left(a_{1}-a_{2}\right)^{2}+\left(b_{1}-b_{2}\right)^{2}} \\
& =\sqrt{((-1,63688)-(-1,52448))^{2}+} \\
& =1,068
\end{aligned}
$$

selanjutnya adalah menghitung jarak antara seluruh objek sehingga nantinya diperoleh matriks jarak antara objek.

\section{Analisis Cluster Hirarki Metode Average Linkage}

Dengan menggunakan metode Average Linkage bahwa objek nomor 2 (Kab. Bulukumba) dan nomor 11 (Kab. Bone) bergabung menjadi satu cluster, karena memiliki jarak paling kecil yaitu 0,044. Hal ini menunjukkan bahwa jarak antara kedua kabupaten tersebut merupakan jarak yang paling dekat dari banyaknya kombinasi jarak 24 kabupaten/kota. Selanjutnya pada tahap kedua jarak yang terdekat adalah objek nomor 14 (Sindereng Rappang) bergabung dengan nomor15 (Pinrang) dengan jarak yaitu 0,147. Demikian seterusnya, sehingga semua objek bergabung menjadi satu cluster. Hasil dari proses ini ditampilkan dalam Gambar 4.1 sebagai berikut :

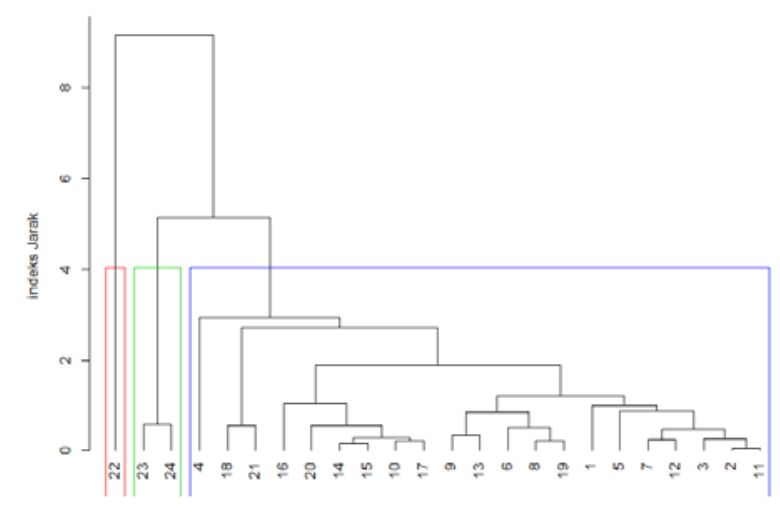

\section{Gambar 4.1 Dendrogram Analisis Cluster Metode Average Linkage}

Pada Gambar 4.1 menunjukkan bahwa terdapat 3 kelompok/cluster yaitu cluster 1 terdiri 21 Kabupaten/Kota,cluster 2 terdiri dua Kabupaten/Kota, dan cluster 3 terdiri satu
Kabupaten/Kota. Dalam hal ini dapat dilihat

\begin{tabular}{|c|c|}
\hline Cluster & Kabupaten/Kota \\
\hline Cluster 1 & $\begin{array}{l}\text { Kepulauan Selayar, Gowa, Barru, } \\
\text { Sidenreng Rappang, Pinrang, Luwu } \\
\text {, Luwu Timur, Bulukumba, } \\
\text { Bantaeng, Sinjai, Maros, } \\
\text { Pangkajenne Kepulauan, Bone, } \\
\text { Soppeng, Wajo, Luwu Utara, } \\
\text { Takalar, Tana Toraja, Toraja Utara, } \\
\text { Enrekang, dan Jeneponto }\end{array}$ \\
\hline Cluster 2 & Palopo,dan Pare-Pare \\
\hline Cluster 3 & Makassar \\
\hline
\end{tabular}
dalam Tabel 4.6 sebagai berikut:

\section{Tabel 4.6 Cluster dan Anggotanya}

\section{Interpretasi Cluster}

Dalam hal menginterpretasikan hasil cluster digunakan nilai-nilai rata-rata (centroid) tiap cluster. Nilai centroid tiap cluster diperoleh sebagaimana dalam Tabel 4.6 berikut ini :

Tabel 4.6 Centroid Cluster

\begin{tabular}{|c|c|c|c|}
\hline Variabel & Cluster 1 & Cluster 2 & Cluster 3 \\
\hline $\mathrm{X}_{1}$ & $-0,18246$ & $-0,37419$ & 4,58011 \\
\hline $\mathrm{X}_{2}$ & $-0,2423$ & 0,23878 & 4,61066 \\
\hline $\mathrm{X}_{4}$ & $-0,25548$ & 1,24739 & 2,87021 \\
\hline $\mathrm{X}_{6}$ & $-0,14603$ & 0,8518 & 1,36312 \\
\hline $\mathrm{X}_{7-}$ & $-0,25127$ & 1,69986 & 1,87695 \\
\hline $\mathrm{X}_{8}$ & $-0,32433$ & 2,09727 & 2,61634 \\
\hline $\mathrm{X}_{9}$ & $-0,29993$ & 2,08859 & 2,12137 \\
\hline $\mathrm{X}_{10}$ & $-0,27147$ & 1,70375 & 2,29325 \\
\hline $\mathrm{X}_{11}$ & 0,29938 & $-1,97968$ & $-2,32766$ \\
\hline
\end{tabular}

\section{KESIMPULAN DAN SARAN}

Berdasarkan analisis dan pembahasan, maka dapat disimpulkan hasil pengelompokkan Kabupaten/Kota di provinsi Sulawesi Selatan berdasarkan indikator kesejahteraan rakyat dengan menggunakan metode Average Linkageyaitu :

1. Cluster 1 terdiri 21 kabupaten/kota, dengan indikator oleh variabel Kepemilikan Rumah Sendiri ( $\left.\mathrm{X}_{11}\right)$. Selain dari variabel PDRB $\left(\mathrm{X}_{1}\right)$ dan Kepemilikan Rumah Sendiri ( $\mathrm{X}_{11}$ ) untuk ketujuh variabel lainnya memiliki rata-rata nilai centroid yang paling rendah di antara cluster lainnya.

2. Cluster 2 terdiri dua kabupaten/kota. Dengan indikator terhadap variabel Rata-Rata Lama Sekolah. Cluster 2, untuk variabel PDRB $\left(\mathrm{X}_{1}\right)$ memiliki rata-rata yang paling rendah. 
Sedangkan untuk kedelapan variabel lainnya memiliki rata-rata nilai centroid yang cukup tinggi (sedang).

3. Cluster 3 terdiri satu kabupaten/kota yaitu, Kota Makassar dengan variabel yang mempengaruhi yaitu variabel Kepadatan Penduduk $\left(\mathrm{X}_{2}\right)$. Pada Cluster ini untuk kedelapan variabel lainnya memiliki rata-rata nilai centroid yang paling tinggi diantara cluster lainnya. Sedangkan untuk variabel Kepemilikan Rumah Sendiri ( $\left.\mathrm{X}_{11}\right)$ memiliki rata-rata nilai centroid paling rendah.

Untuk penelitian selanjutnya, peneliti menyarankan untuk penggunaan metode yang lain dalam analisis cluster hirarki sehingga dapat menjadi bahan perbandingan hasil analisis.

\section{DAFTAR PUSTAKA}

[1] Badan Pusat Statistik Provinsi Sulawesi Selatan. 2015. "Indikator Kesejahteraan Rakyat Sulawesi Selatan Tahun 2015”. Makassar : BPS Provinsi Sulawesi Selatan.

[2] Ermawati. 2012. "Statistika Multivariat Terapan”. Makassar : Alauddin University Press.

[3] Johnson, Richard \& Dean. 2007. “Applied Multivariate Statistical Analysis Sixth Edition”. New York: Prentice-Hall International.Mattjik, Ahmad Ansori \& I Made Sumertajaya, "Sidik Peubah Ganda dengan Menggunakan SAS” . Bogor : IPB Press.

[4] Laraswati, Tri Febriana. 2014. Perbandingan Kinerja Metode Complete, Linkage Metode Average Linkage, dan Metode K-means Dalam Menentukan Hasil Analisis Cluster. Yogyakarta : Universitas Negeri Yogyakarta.

[5] Machfudhoh, Siti dan Nuri Wahyuningsih. "Analisis Cluster Kabupaten/Kota Berdasarkan Pertumbuhan Ekonomi Jawa Timur”. Jurnal Sains Dan Seni Pomits, Vol. 2, No.1 (2013).http://digilib.its.ac.id/ public/ITS-paper-3759 7-1 210100028paper.pdf. 